\title{
A comparative study of regional logistics competitiveness in Anhui province
}

\author{
Jingyan $\mathrm{Xu}^{1, *}$, and Qiqi Zhang ${ }^{2}$ \\ ${ }^{1}$ Logistics Management, School of Management, Anhui Business and Technology College, 16 Jinning \\ Road Hefei Anhui, China \\ ${ }^{2}$ Accounting, School of Accounting, Anhui University of Finance and Economics, 962 Caoshan Road \\ Bengbu Anhui, China
}

\begin{abstract}
Based on the data of Anhui Province from 2009 to 2018, this paper analyzed the logistics competitiveness of Anhui Province, Northern Anhui, Central Anhui and Southern Anhui from three dimensions: basic support for logistics development, potential of logistics development and effectiveness of logistics development. In general, the logistics competitiveness of Anhui Province, Central Anhui, Northern Anhui and Southern Anhui from 2009 to 2018 has shown an upward trend year by year, with the three regions competing with one another. Among them, the basic support for logistics development has went from Central Anhui leading, to Northern Anhui, Southern Anhui being on a par with one another and having a balanced development; the effectiveness of logistics development in Northern Anhui has been developing particularly rapid and prominent; the potential of logistics development in three regions has shown little difference and the dynamic developing trend is similar. Suggestions are put forward: improving the policies and environment for logistics development, speeding up the construction of logistics information platform, attaching importance to the training and introduction of logistics talents.
\end{abstract}

\section{Introduction}

The regional logistics competitiveness level is a key indicator to measure regional economic development. Improving regional logistics competitiveness is an important way to ensure sustainable economic development. Researches on regional logistics competitiveness mostly focuse on two perspectives. One is horizontal comparison among provinces and regions. Sun Qinglan and Chen Haoxing (2016) used entropy method and comprehensive evaluation method to evaluate the logistics competitiveness level of the 6 node cities of "the Belt and Road Initiatives", with the result followed by Xi'an, Xiamen, Quanzhou, Urumqi, Lanzhou, Haikou ${ }^{[1]}$. Zong Huiming, Ye Jianhui and Cai Bingjie (2017) used the AHP model and entropy method to compare the logistics competitiveness level of 12 western cities, and found the pattern of "one major-minor, multiple centers" of logistics space in the west $^{[2]}$. Li Pan, Peng Huiping (2018) used grey correlation method to analyze the logistics competitiveness level of 9 provinces in "the Belt and Road Initiatives" economic region,

\footnotetext{
* Corresponding author: xjy_0910@163.com
} 
which followed by Sichuan, Chongqing, Guangxi, Shaanxi, Yunnan, Xinjiang, Gansu, Ningxia, Qinghai ${ }^{[3]}$. Zhang Yanhua (2019) used grey correlation to measure the logistics competitiveness level of Jiangsu, Zhejiang, Shanghai and Anhui, which shows an unbalanced logistics competitiveness level among regions. Jiangsu and Zhejiang have the fastest development, and Anhui has the slowest development ${ }^{[4]}$. The other is longitudinal comparison of different years in the same region. Zhou Jinyu and Luo Yao (2016) compared the logistics competitiveness level of Beibu Gulf in 2008, 2010 and 2013 by using the comprehensive evaluation method. The study showed that the overall logistics competitiveness of Beibu Gulf was low and the development was uneven ${ }^{[5]}$. Cao Bingru and Cao Huihui (2018) used the ANP-TOPSIS method to analyze the logistics competitiveness level of Jiangsu Province in 2006, 2010, and 2016, and found that the logistics development of Jiangsu Province is strong in the south and weak in the north ${ }^{[6]}$. Fang Xiuli and Wu Zhuoliang (2016) selected data of Anhui Province from 1998 to 2014, and found that logistics competitiveness level developed slowly before 2003, and relatively fast after 2003 through principal component analysis ${ }^{[7]}$.

There are few existing studies on the evaluation of logistics competitiveness among regions in provincial level. Combining the characteristics of regional logistics development of Anhui, the study construct a logistics competitiveness evaluation index system, using principal component analysis, dynamically comparing Anhui Province and Northern Anhui (Fuyang, Huaibei, Bengbu, Suzhou, Bozhou, Huainan), Central Anhui (Hefei, Anqing, Chuzhou, Lu'an), Southern Anhui (Wuhu, Maanshan, Xuancheng, Huangshan, Chizhou, Tongling), aiming to provide feasible suggestions for coordinated development of regional logistics.

\section{Data processing}

\subsection{Indicator selection and data sources}

Combining with the logistics development situation of Anhui and learning from scholars' existing logistics competitiveness index system, the study measure the regional logistics competitiveness level within 3 dimensions and 12 indicators, from the basic support for logistics development $\left(\mathrm{X}_{1}\right.$ Internet users, $\mathrm{X}_{2}$ mobile phone users at the end of the year, $\mathrm{X}_{3}$ transportation financial expenditure, $\mathrm{X}_{4}$ highway mileage $)^{[8,9]}$, the effectiveness of logistics development $\left(\mathrm{X}_{5}\right.$ the number of civilian transport ships, $\mathrm{X}_{6}$ the number of civilian trucks, $\mathrm{X}_{7}$ total freight, $\mathrm{X}_{8}$ total post and telecommunications business) ${ }^{[8,10]}$ and the potential of logistics development $\left(\mathrm{X}_{9}\right.$ tertiary industry output value, $\mathrm{X}_{10}$ the number of students in colleges and universities, $\mathrm{X}_{11}$ transportation, storage and postal industry construction project investment, $\mathrm{X}_{12}$ transportation, storage, post and telecommunications industry population) ${ }^{[11,12]}$. Data source from 2009-2018 China City Statistical Yearbook and Anhui Statistical Yearbook.

\subsection{Data analysis}

Standardize the index data of Anhui Province, Northern Anhui, Central Anhui, and Southern Anhui from 2009 to 2018, then use principal component analysis to analyze logistics competitiveness indicators with SPSS 22.0. The KMO values of Anhui Province, Northern Anhui, Central Anhui, and Southern Anhui are all greater than 0.7, and the significance levels are all 0.000 . The principal components selected with eigenvalues above 1.0 are shown in Table 1, and the component loads after rotation are shown in Table 2 and Table 3. 
Table 1. Principal component analysis of regional logistics competitiveness level.

\begin{tabular}{|c|c|c|c|c|}
\hline Dimension & Region & $\begin{array}{l}\text { Principal } \\
\text { components }\end{array}$ & Eigenvalues & $\begin{array}{c}\text { Variance } \\
\text { contribution } \%\end{array}$ \\
\hline \multirow{8}{*}{$\begin{array}{l}\text { The comprehensive } \\
\text { regional logistics } \\
\text { competitiveness level }\end{array}$} & \multirow[t]{2}{*}{ Anhui Province } & 1 & 8.307 & 69.222 \\
\hline & & 2 & 2.963 & 24.693 \\
\hline & \multirow[t]{2}{*}{ Northern Anhui } & 1 & 8.179 & 68.162 \\
\hline & & 2 & 2.975 & 24.782 \\
\hline & \multirow{2}{*}{ Central Anhui } & 1 & 8.276 & 68.963 \\
\hline & & 2 & 2.679 & 22.328 \\
\hline & \multirow[t]{2}{*}{ Southern Anhui } & 1 & 7.378 & 61.481 \\
\hline & & 2 & 3.243 & 27.024 \\
\hline \multirow{4}{*}{$\begin{array}{l}\text { The basic support for } \\
\text { logistics development }\end{array}$} & Anhui Province & 1 & 3.860 & 96.496 \\
\hline & Northern Anhui & 1 & 3.578 & 89.447 \\
\hline & Central Anhui & 1 & 3.772 & 94.300 \\
\hline & Southern Anhui & 1 & 3.833 & 95.813 \\
\hline \multirow{4}{*}{$\begin{array}{l}\text { The effectiveness of } \\
\text { logistics development }\end{array}$} & Anhui Province & 1 & 3.554 & 88.844 \\
\hline & Northern Anhui & 1 & 3.761 & 94.037 \\
\hline & Central Anhui & 1 & 3.160 & 78.944 \\
\hline & Southern Anhui & 1 & 3.045 & 76.113 \\
\hline \multirow{4}{*}{$\begin{array}{l}\text { The potential of } \\
\text { logistics development }\end{array}$} & Anhui Province & 1 & 3.101 & 77.513 \\
\hline & Northern Anhui & 1 & 3.019 & 75.480 \\
\hline & Central Anhui & 1 & 2.995 & 74.882 \\
\hline & Southern Anhui & 1 & 2.961 & 72.911 \\
\hline
\end{tabular}

Table 2. Component load after rotation of the comprehensive regional logistics competitiveness level.

\begin{tabular}{ccccccccc}
\hline Index & \multicolumn{2}{c}{ Anhui Province } & \multicolumn{2}{c}{ Northern Anhui } & \multicolumn{2}{c}{ Central Anhui } & \multicolumn{2}{c}{ Southern Anhui } \\
& Component & \multicolumn{2}{c}{ Component } & \multicolumn{2}{c}{ Component } & \multicolumn{2}{c}{ Component } \\
& 1 & 2 & 1 & 2 & 1 & 2 & 1 & 2 \\
\hline X1 & 0.947 & 0.304 & 0.862 & 0.396 & 0.972 & 0.191 & 0.933 & 0.343 \\
X2 & 0.809 & 0.569 & 0.777 & 0.603 & 0.820 & 0.552 & 0.805 & 0.576 \\
X3 & 0.935 & 0.295 & 0.899 & 0.360 & 0.954 & 0.226 & 0.902 & 0.339 \\
X4 & 0.949 & 0.267 & 0.952 & 0.027 & 0.886 & 0.316 & 0.941 & 0.297 \\
X5 & 0.533 & 0.701 & 0.773 & 0.540 & 0.196 & 0.852 & 0.697 & 0.554 \\
X6 & 0.792 & 0.592 & 0.839 & 0.528 & 0.727 & 0.666 & 0.549 & 0.746 \\
X7 & 0.844 & 0.503 & 0.817 & 0.509 & 0.915 & 0.386 & 0.407 & 0.632 \\
X8 & 0.939 & 0.248 & 0.773 & 0.540 & 0.196 & 0.852 & 0.697 & 0.554 \\
X9 & 0.946 & 0.302 & 0.943 & 0.309 & 0.960 & 0.266 & 0.953 & 0.251 \\
X10 & 0.825 & 0.560 & 0.722 & 0.661 & 0.877 & 0.462 & 0.704 & 0.676 \\
X11 & 0.946 & 0.149 & 0.923 & 0.195 & 0.968 & 0.025 & 0.960 & 0.146 \\
X12 & -0.076 & -0.897 & -0.077 & -0.918 & -0.086 & -0.745 & 0.018 & -0.845 \\
\hline
\end{tabular}


Table 3. Component load after 3-dimesnsion rotation.

\begin{tabular}{cccccc}
\hline Dimension & Indicators & $\begin{array}{c}\text { Anhui } \\
\text { Province }\end{array}$ & $\begin{array}{c}\text { Northern } \\
\text { Anhui }\end{array}$ & $\begin{array}{c}\text { Central } \\
\text { Anhui }\end{array}$ & $\begin{array}{c}\text { Southern } \\
\text { Anhui }\end{array}$ \\
\hline \multirow{2}{*}{ The basic support for } & X1 & 0.990 & 0.977 & 0.966 & 0.989 \\
logistics development & X2 & 0.962 & 0.947 & 0.962 & 0.970 \\
& X3 & 0.988 & 0.979 & 0.982 & 0.978 \\
& X4 & 0.988 & 0.874 & 0.975 & 0.979 \\
The effectiveness of & X5 & 0.883 & 0.927 & 0.683 & 0.940 \\
logistics development & X6 & 0.995 & 0.986 & 0.980 & 0.913 \\
& X7 & 0.976 & 0.950 & 0.965 & 0.767 \\
The potential of & X8 & 0.911 & 0.899 & 0.896 & 0.859 \\
logistics development & X10 & 0.975 & 0.954 & 0.980 & 0.961 \\
& X11 & 0.973 & 0.941 & 0.978 & 0.932 \\
& X12 & -0.575 & -0.628 & -0.452 & -0.513 \\
\hline
\end{tabular}

\section{Measurement of regional logistics competitiveness level}

\subsection{Indicator selection and data sources}

Divide the data in the component load tables of Table 2 and Table 3 by the square root of the corresponding eigenvalue to obtain the coefficient a of each principal component. The score of each principal component is:

$$
f=a_{1} x_{1}+a_{2} x_{2}+a_{3} x_{3}+\cdots+a_{m} x_{m}
$$

Where $\mathrm{m}$ is the number of indicators of the principal component. Taking the variance contribution rate corresponding to the principal component as the weight, the comprehensive score of each dimension can be obtained:

$$
F=\alpha_{1} f_{1}+\alpha_{2} f_{2}+\alpha_{3} f_{3}+\cdots+\alpha_{i} f_{i}
$$

Where $\alpha$ is the variance contribution rate of the principal component and $\beta$ is the cumulative variance contribution rate. The results are shown in Table 4.

\begin{tabular}{|c|c|c|c|c|c|c|c|c|c|c|c|}
\hline Dimension & Region & 2009 & 2010 & 2011 & 2012 & 2013 & 2014 & 2015 & 2016 & 2017 & 2018 \\
\hline \multirow{4}{*}{$\begin{array}{l}\text { The } \\
\text { comprehensive } \\
\text { regional } \\
\text { logistics } \\
\text { competitiveness } \\
\text { level }\end{array}$} & $\begin{array}{l}\text { Anhui } \\
\text { Province }\end{array}$ & $\begin{array}{l}- \\
0.13\end{array}$ & 0.19 & 0.49 & 0.87 & 1.42 & 1.68 & 2.08 & 2.36 & 2.69 & 3.00 \\
\hline & $\begin{array}{l}\text { Northern } \\
\text { Anhui }\end{array}$ & $\overline{0}-15$ & 0.16 & 0.58 & 0.83 & 1.07 & 1.41 & 1.83 & 2.17 & 2.46 & 2.99 \\
\hline & $\begin{array}{l}\text { Central } \\
\text { Anhui }\end{array}$ & $\begin{array}{l}- \\
0.10\end{array}$ & 0.20 & 0.34 & 0.74 & 1.30 & 1.36 & 1.73 & 1.93 & 2.14 & 2.42 \\
\hline & $\begin{array}{l}\text { Southern } \\
\text { Anhui }\end{array}$ & $\overline{0}-11$ & 0.18 & 0.41 & 0.84 & 1.44 & 1.75 & 2.03 & 2.08 & 2.40 & 2.83 \\
\hline \multirow{3}{*}{$\begin{array}{l}\text { The basic } \\
\text { support for } \\
\text { logistics } \\
\text { development }\end{array}$} & $\begin{array}{l}\text { Anhui } \\
\text { Province }\end{array}$ & 0.02 & 0.10 & 0.18 & 0.39 & 0.76 & 1.06 & 1.41 & 1.53 & 1.85 & 1.95 \\
\hline & $\begin{array}{l}\text { Northern } \\
\text { Anhui }\end{array}$ & 0.00 & 0.08 & 0.20 & 0.37 & 0.58 & 0.79 & 1.31 & 1.37 & 1.68 & 1.96 \\
\hline & Central & 0.05 & 0.13 & 0.17 & 0.40 & 0.81 & 1.15 & 1.45 & 1.59 & 1.93 & 1.90 \\
\hline
\end{tabular}

Table 4. The regional logistics competitiveness level of 2009-2018. 


\begin{tabular}{|c|c|c|c|c|c|c|c|c|c|c|c|}
\hline & $\begin{array}{l}\text { Anhui } \\
\text { Southern } \\
\text { Anhui }\end{array}$ & 0.00 & 0.07 & 0.21 & 0.39 & 0.82 & 1.10 & 1.36 & 1.50 & 1.75 & 1.95 \\
\hline \multirow{4}{*}{$\begin{array}{l}\text { The } \\
\text { effectiveness of } \\
\text { logistics } \\
\text { development }\end{array}$} & $\begin{array}{l}\text { Anhui } \\
\text { Province }\end{array}$ & 0.03 & 0.09 & 0.44 & 0.74 & 1.23 & 1.25 & 1.46 & 1.62 & 1.62 & 1.86 \\
\hline & $\begin{array}{l}\text { Northern } \\
\text { Anhui }\end{array}$ & 0.03 & 0.04 & 0.52 & 0.69 & 0.82 & 1.00 & 1.15 & 1.56 & 1.57 & 1.95 \\
\hline & $\begin{array}{l}\text { Central } \\
\text { Anhui }\end{array}$ & 0.03 & 0.12 & 0.41 & 0.72 & 1.41 & 1.21 & 1.36 & 1.50 & 1.51 & 1.63 \\
\hline & $\begin{array}{l}\text { Southern } \\
\text { Anhui }\end{array}$ & 0.49 & 0.16 & 0.24 & 0.40 & 0.59 & 0.74 & 0.91 & 0.94 & 1.25 & 1.55 \\
\hline \multirow{4}{*}{$\begin{array}{l}\text { The potential of } \\
\text { logistics } \\
\text { development }\end{array}$} & $\begin{array}{l}\text { Anhui } \\
\text { Province }\end{array}$ & 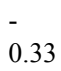 & 0.15 & 0.28 & 0.45 & 0.58 & 0.73 & 0.88 & 1.11 & 1.40 & 1.62 \\
\hline & $\begin{array}{l}\text { Northern } \\
\text { Anhui }\end{array}$ & $\begin{array}{l}- \\
0.36\end{array}$ & 0.18 & 0.35 & 0.45 & 0.53 & 0.78 & 0.87 & 1.01 & 1.26 & 1.61 \\
\hline & $\begin{array}{l}\text { Central } \\
\text { Anhui }\end{array}$ & $\begin{array}{l}- \\
0.27\end{array}$ & 0.13 & 0.24 & 0.47 & 0.58 & 0.65 & 0.86 & 1.21 & 1.47 & 1.60 \\
\hline & $\begin{array}{l}\text { Southern } \\
\text { Anhui }\end{array}$ & $\begin{array}{l}- \\
0.30\end{array}$ & 0.16 & 0.26 & 0.43 & 0.60 & 0.76 & 0.89 & 0.95 & 1.30 & 1.62 \\
\hline
\end{tabular}

\section{Empirical comparison}

\subsection{The analysis of regional logistics competitiveness in Anhui Province}

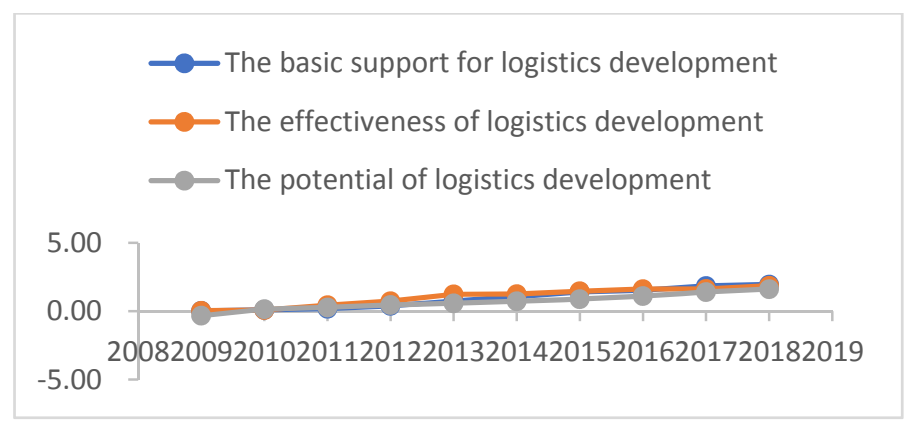

Fig. 1. The 3 dimension of regional logistics competitiveness level in Anhui Province.

It can be seen from Table 4 that the overall regional logistics competitiveness level in Anhui has been increasing year by year. From Figure 1, it can be seen that the potential of logistics development, the effectiveness of logistics development, and the basic support for logistics development level from 2009 to 2018 have been continuously improved, with the highest performance of the effectiveness of logistics development during 2009-2016. The potential of logistics development in 2017 and 2018 surpassed the effectiveness of logistics development. This is inseparable from the increase in transportation financial expenditures and the strengthening of transportation network construction in Anhui. In addition, the popularization of the Internet, in particular the mobile Internet, and the widespread use of mobile phones as Internet terminals have promoted the construction and development of logistics infrastructure to a certain extent.

In general, the logistics competitiveness of Anhui Province, Central Anhui, Northern Anhui and Southern Anhui has shown an upward trend year by year from 2009 to 2018, with Central Anhui, Southern Anhui, and Northern Anhui competing with each other fiercely. Specifically, the logistics competitiveness of Central Anhui from 2009 to 2010 was higher than that of Anhui Province as a whole, Northern Anhui and Southern Anhui, mainly because Hefei's comprehensive logistics development capability and status quo stood out in the 
province and has been the regional logistics node nationally. In 2012-2015, the logistics competitiveness of Southern Anhui surpassed that of Central Anhui, and was higher than that of Northern Anhui. This is because Wuhu and Ma'anshan, the water and land transportation hubs in Southern Anhui, have geographical advantageous locations, rapid economic development, large demand for industrial and commercial logistics and strong logistics supply capacity. From 2016 to 2018, the logistics competitiveness of Northern Anhui surpassed that of Central Anhui and Southern Anhui, and develop so rapidly that the gap between Central Anhui and the other two regions widened. This is related to the regional development strategy of Anhui Province to promote logistics development. The effect of Northern Anhui was the most obvious. Especially Fuyang, one of the second-tier cities of the national logistics park, is an important transportation hub in northwest Anhui. Bengbu, the city of the layout of national logistics hub, holds outstanding transportation and location advantages.

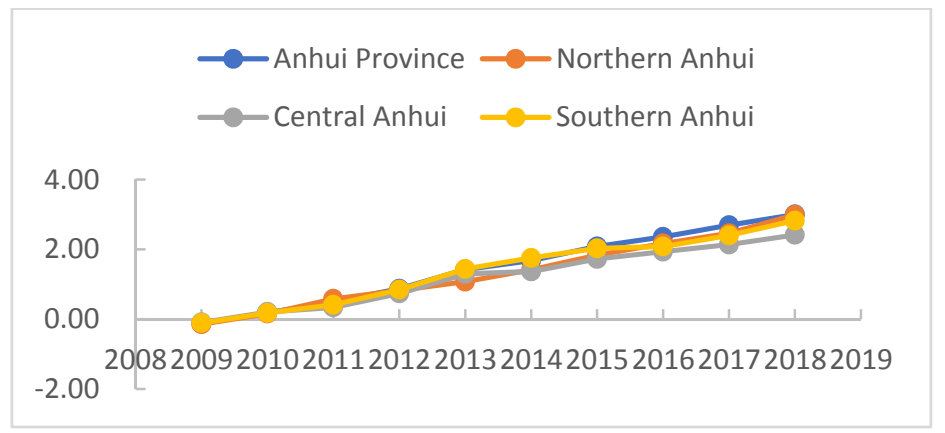

Fig. 2. The comparison of comprehensive regional logistics competitiveness level.

\subsection{The comparison of support for logistics development}

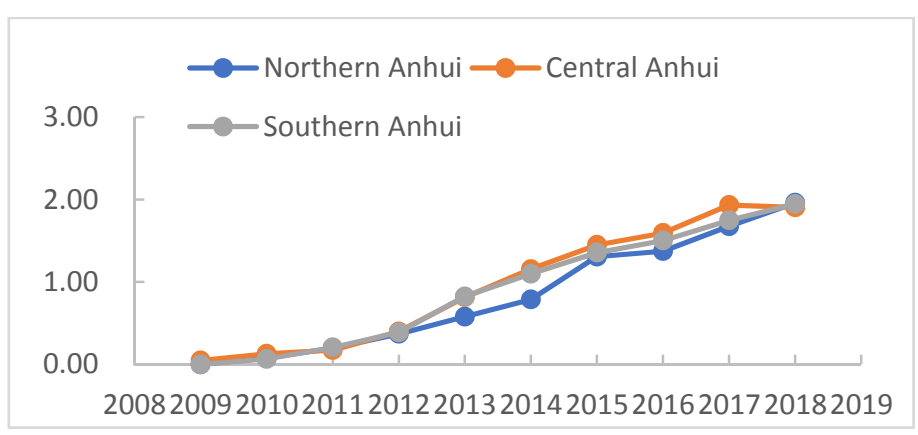

Fig. 3. The comparison of the support level for logistics development.

The results show that the basic support for logistics development of Central Anhui from 2009 to 2017 is higher than that of Northern Anhui and Southern Anhui. This is mainly due to the fact that Hefei in Central Anhui has highly developed expressway network, large transportation financial expenditures, and a significant position in the logistics industry. The basic support for logistics development level in Northern Anhui, Central and Southern Anhui tended to be convergent in 2018, indicating that Anhui Province has begun to attach importance to the balanced development of regional logistics support, continuously improve infrastructure conditions, and optimize the logistics development environment. 


\subsection{The comparison of logistics development effectiveness}

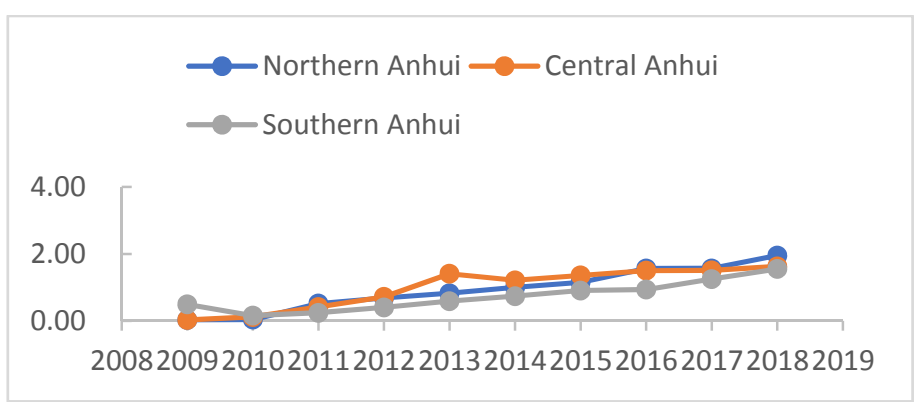

Fig. 4. The comparison of the effectiveness level of logistics development.

From Table 4 and Figure 4, it can be seen that the logistics development in Southern Anhui achieved the best results in 2009, mainly related to the rapid economic development of Ma'anshan and Wuhu. The larger the economic scale, the larger the total volume of post and telecommunications business and the total volume of freight. Since 2010, after a sudden decrease in the logistics development effectiveness of Southern Anhui, it began to increase steadily. From 2012 to 2015, the level of Central Anhui was higher than that of Northern Anhui and Southern Anhui due to the remarkable results of the logistics development in Central Anhui. During this period, Hefei and Anqing were announced the cities of logistics park for the first-level and the second-level respectively, Hefei Airport Logistics Park was formed initially, Hefei Comprehensive Bonded Zone and Export Processing Zone, Anqing Bonded Logistics Center, etc. were approved.

From 2016 to 2018, the effectiveness of logistics development level ranks in the order of Northern Anhui, Central Anhui, and Southern Anhui. In accordance with the Notice of the National Development and Reform Commission on Printing and Distributing the "Threeyear Action Plan for Promoting the Development of the Logistics Industry (2014-2016)", Anhui Province integrated logistics resources, cultivated logistics market players, and created a new logistics environment. The amount of foreign trade freight volume of Fuyang in Northern Anhui was considerable, as well as the commerce and logistics industry developed rapidly with the multi-modal linkage gradually converging and radiating to drive the surrounding cities, promoting the development of logistics in Northern Anhui to be higher than that of Central and Southern Anhui.

\subsection{The comparison of logistics development potential}

It can be seen from Figure 5 that the potential of logistics development in three regions has been increasing year by year with relatively fast growth rate. The potential level of logistics development in Northern Anhui and Southern Anhui from 2009 to 2018 differed very little, and had similar dynamic developing trend. In 2016-2017, the potential level of Central Anhui is slightly higher than that of Northern and Southern Anhui. In 2018, the potential level of the three regions tended to be consistent. It shows that Anhui Province, by creating good logistics policy environment, formulating relevant regional logistics development strategies and attaching importance to the balanced and coordinated development of regional logistics, has improved the comprehensive logistics level in the province. 


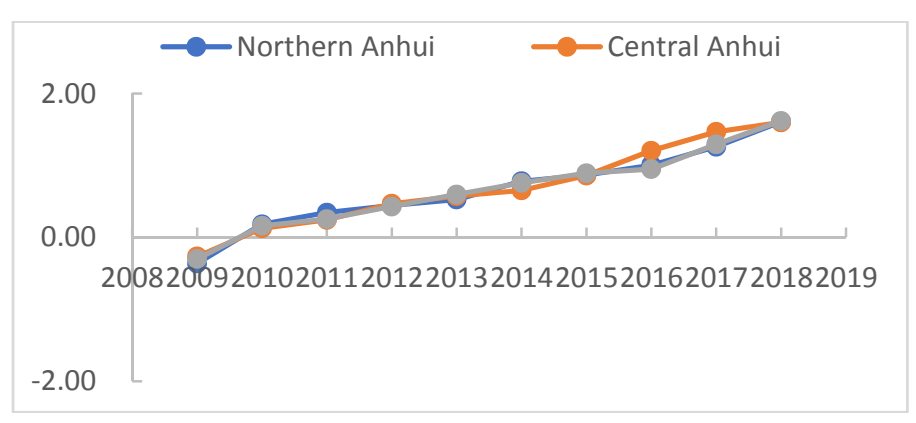

Fig. 5. The comparison of the potential level of logistics development.

\section{Conclusions and suggestions}

According to the above analysis, the overall level of logistics competitiveness of Anhui increased year by year from 2009 to 2018. Anhui Province has begun to attach importance to the balanced development of regional logistics support since 2016. The basic support level of logistics development of Northern Anhui, Central Anhui, and Southern Anhui has seen similar trend gradually. The effectiveness level of logistics development in Northern Anhui has been stable and fast, surpassing that of Central Anhui and ranking the highest in the province in 2016-2018. The potential level of logistics development of the three regions had similar dynamic change trend and little difference, and rises steadily. Combined with data analysis and regional logistics competitiveness comparison, the study put forward the following regional logistics development suggestions.

\subsection{Improve the logistics development policy and the logistics development environment}

First, gradually form the policy system to promote logistics development, focusing on supporting the construction of national logistics parks cities, such as Hefei, Fuyang, and Wuhu, so that they can radiate and drive the development of surrounding cities, rationally plan transportation networks, and strengthen transportation infrastructure construction to improve the situation of unbalanced regional logistics development level. Secondly, optimize the institutional environment for logistics development, support excellent logistics enterprises, enable them to play a leading role, help small and medium logistics enterprises become bigger and stronger, and enable logistics enterprises to form a standardized logistics system according to the needs of leading industries, so as to promote business cooperation inter-regionally.

\subsection{Accelerate the construction of logistics information platform}

Based on the logistics hub network in Northern Anhui, Central Anhui, and Southern Anhui, accelerate the deployment of regional logistics information platforms, release regional logistics demand information, realize the exchange and sharing of logistics information, logistics technology, and logistics equipment and whole process control, and strengthen the application of the Internet of Things and big data. Build smart logistics, optimize the allocation of logistics resources, and improve the efficiency of logistics operations, so that industry, trade, and agricultural companies can closely connect with logistics companies, and realize the reciprocal interoperability of logistics systems in northern, central and southern Anhui. 


\subsection{Attach importance to the introduction and training of logistics talents}

Talents are the basis and guarantee for the development of logistics. It can be seen from the statistical data that the average number of students enrolled in colleges and universities from 2009 to 2018 was 36,706 in Northern Anhui, 132,027 in Central Anhui, and 42,627 in Southern Anhui. The unbalanced potential of logistics talents among three regions is an important factor restricting the development of the logistics industry. Therefore, it is necessary to strengthen the training of logistics talents in colleges and universities based on the characteristics of logistics development in Anhui Province. Giving full play to Hefei's advantageous higher education resources, transport its logistics talents to cities lacking higher educational resources. At the same time, strengthen the vocational training of on - the - job personnel and introduce high-level logistics professionals to meet the needs of modern logistics and regional economic development.

\section{Acknowledgements}

Thanks for the financial support of Anhui's colleges social science research project in 2020: "Research on the Anhui's spatiotemporal evolution mechanism and coordinated development of logistics industry and information industry in the new era (SK2020B001)".

\section{References}

1. Q. L. Sun, H. X. Chen. A Study on the Evaluation of the Competitiveness of Logistics Industry in Some Node Cities Along "Belt and Road". J. Ry Trans Econ. 38, 9 (2016)

2. H. M. Zong, J. H. Ye. Evaluation of Logistics Competitiveness of Logistics Node Cities in Western Region. J. Southwest U: Nat Sci Ed. 42, 2 (2017)

3. P. Li, H. P. Peng. Evaluation on the Competitiveness of Regional Logistics Industry in the Silk Road Economic Belt. J. Xi'an Inst Financ Econ. 31, 3 (2018)

4. Y. H. Zhang. Comparative Study on the Development Competitiveness of Logistics Industry in Yangtze River Delta Region — Based on the Empirical Study of Jiangsu, Zhejiang, Anhui and Shanghai. J. Bus Econ Res. 10 (2019)

5. J. Y. Zhou, Y. Luo. Dynamic Comparison of Urban Logistics Competitiveness in the Beibu Gulf Economic Zone. J. Cst Ent Tech. 1 (2016)

6. B. R. Cao, H. H. Cao. ANP-TOPSIS Evaluation of Regional Logistics Development Ability_-Taking Jiangsu Province as an Example. J. Regn Res Dev. 37, 4 (2018)

7. X. L. Fang, Z. L. Wu. Evaluation of the Competitiveness of Logistics Industry in Anhui Province and its Impact on the Performance of Competition. J. Chongqing Inst Sci Tech. 3 (2016)

8. L. J. Zheng. Cluster Analysis on Regional Logistics Competitiveness of Port Cities Along the "Belt and Road". J. Bus Econ Res. 24 (2016)

9. L. Liu, Y. F. Deng. The Empirical Study on the Relationship between Logistics Competitiveness and Economic Growth _ Taking the Data of Sichuan Province from 1997 to 2013 as an Example. J. Log Tech. 35, 9 (2016)

10. Y. M. Liu. The Empirical Study on the Analysis and Evaluation of Regional Logistics Competitiveness Level — Taking Hunan Province as an example. J. Log Tech. 32, 1 (2013)

11. H. B. Guo Hubin, Z. T. Deng. A Study on the Coordinated Development of Regional Logistics and Regional Economic Coupling in the Yangtze River Economic Belt. J. Contemp Econ Manage. 5 (2019)

12. C. Zhang, Y. Zhang. Evaluation and Cluster Analysis of Logistics Competitiveness in Jiangxi Province. J. Chin Log Tech. 33, 8 (2014) 